\title{
Savaşın Toplumsal Etkileri Bağlamında Suriye İç Savaşı ve Sanat
}

Doç. Dr. Asuman Aypek Arslan

Makale Geliş Tarihi: 14.04.202I Semra Kayıkçı Kotan

\section{Özet}

Savaş olgusu sanatsal pratikler içerisinde sıkça kullanılan bir tema olmuştur. Suriye iç̧ Savaşı ise 202 yilı itibariyle hala devam etmekte ve beraberinde yașananlarla hem toplumu hem de sanatı etkilediğ görülmüstür Dolayısyla "Surive Ic Savas bağlamında savașın toplumsal ve sanatsal pratiklere etkisi nedir?" sorusu bu araștırmanın problemini olușturmuștur. Araștırmanın konusunun güncel olmas literatüre katkısı açııından önemlidir. Araştırmanın amacı hala sürmekte olan bir savaşa sanatın ve sanatçının perspektifinden bakmak ve sanatın tasvir etme gücünü incelemektir. Nitel araştırma yöntemi ile incelenen bu araştırma tarama ve doküman analiz tekniği ile yapılmıştır. Araştırma evreni olan Suriye iç Savaşından Ai Weiwei, Banksy ve Tammam Azzam örneklemleri ile sınırlandırılarak konu irdelenmeye çalısıılmısțı. Seçilen örneklemler üzerinden sanatçıların savaşın toplumsal etkilerine yönelik evrensel boyutlarda dikkat çekme önceliğinde çalıșmalar yaptıkları sonucuna varılmıştır. Diğer yandan görsele ve veriye fazlasıyla maruz kalındığı günümüz dünyasında sorunun olağanlaşmasına karşı sanatçıların savaşın hem bireysel hem de toplumsal yıkıclı̆̆ııı anlatmakta zorlandıkları görülmektedir.

Anahtar Kelimeler: Savaș ve Sanat, Suriye iç Savaşı, Ai Weiwei, Banksy, Tammam Azzam

SYRIAN CIVIL WAR AND ART IN THE CONTEXT OF THE SOCIAL EFFECTS OF THE WAR

\section{Abstract}

The phenomenon of war has been a frequently used theme in artistic practices. The Syrian Civil War, on the other hand, still continues as of 202I, and it has been seen that it has affected both society and art with what happened with it. Therefore, "What is the impact of the war on social and artistic practices in the context of the Syrian Civil War?" This question constituted the problem of this research. It is important that the subject of the research is up-to-date in terms of its contribution to the literature. The aim of the research is to look at an ongoing war from the perspective of art and the artist and examine the power of art to describe. This research, which was examined with the qualitative research method, was carried out with the scanning and document analysis technique. The subject has been tried to be examined by limiting it to the samples of Ai Weiwei, Banksy and Tammam Azzam from the Syrian Civil War, which is the research universe. It was concluded that the artists were working on the social effects of the war with the priority of drawing attention to the universal dimensions, through the selected samples. On the other hand, it is seen that artists have difficulty in explaining both the individual and social destructiveness of the war against the normalization of the problem in today's world where visual and data are heavily exposed.

Keywords: Art and War, Syrian Civil War, Ai Weiwei, Banksy, Tammam Azzam

Doç. Dr. Asuman Aypek Arslan, Ankara Hacı Bayram Veli Üniversitesi, Sanat ve Tasarım Fakültesi, Görsel Sartlar Bölümü, Anka E-p ta: asuman aypek@hbvedu.tr. ORCID: 0000-0002-94002642 


\section{Giriş}

Savaş, sanat için bir tema mı, yoksa sanat savaşın yıkıcılığını göstermede bir araç mı? Insanlık tarihi kadar eski ve ilkel bir yöntem olan savaş, günümüz modern toplumlarında hala bir tercih meselesidir. 2011 yılında başlayıp hala süren Suriye İç Savaşı beraberinde ölümler, acılar ve felaketler getirmeye devam etmektedir. Bütün dünyanın ortak sorunu haline gelen durum ise savaşın doğurduğu mülteci krizidir. Teknolojinin sunduğu imkanlarla savaşın seyri ve mülteci krizi ile ilgili her türlü görüntü ve bilgi anında ulaşmaktadır. Bu durum ise zamanla yaşanan insanlık dramını normalleştirmektedir. Bu nokta da sanatçı ve sanat olgusu yaşanan sorunun evrenselliğine dikkat çekmek amacıyla devreye girmiştir.

İnsanlığın kolektif belleğinin en yıkıcı anılarını savaş ve beraberinde gelen korku, dehşet, yok olus, çaresizlik ve ölüm gibi kavramlar oluşturmaktadır. Bu olumsuz olguların oluşturduğu travmaların arkasında kazanan toplumlar değil genelde politik erk sahipleri olmuştur. Temelde insanlığın en ilkel davranışlarından birinin günümüz modern toplumlarına kadar gelmesi, hatta geçtiğimiz yüzyılda iki büyük Dünya Savaşı'nın gerçekleşmesi, bu ilkel davranışın ve toplumsal travmaların yakın bir tarihte bitmeyeceğini göstermektedir.

2011 yılından beri devam etmekte olan Suriye İç Savaşı ise içinde bulunduğumuz zamanda bütün dünyaya savaşın acılarını canlı canlı seyrettirmektedir. Suriye İç Savaşı beraberinde büyük oranda kitlesel göçleri de getirmiştir. Öncelikle Türkiye gibi Suriye Devleti'ne komşu ülkeler olmak üzere özellikle Avrupa Birliği ülkelerine ve hatta $A B D$ 'ye sığınmacı veya mülteci statüsünde göçler meydana gelmiştir. Bu hayatta kalma yolculukları çoğu zaman savaş kadar dehşet sonuçlar doğurmuştur. Adı "umuda yolculuk" olan fakat toplumsal hafızalarda unutulmayacak acı görüntülerle sonuçlanan bu göçlere karşı sanat da sessiz kalamamıştır.

Savaşın yıkıcılığı, yok ediciliği karşısında sanatın yaratıcılığı ve varoluşsal çabası çelişiyor gibi görünse de sanat ve sanatçı içinden çıktığı toplumun beraber yaşadığı insanlığın acılarına tepkisiz kalmamıştır. Francisco de Goya, "3 Mayıs 1808" adlı eseri ile Napolyon'un askerlerinin İspanya halkına yaşattığı zulme tepkisiz kalmadığı gibi keza Picasso'nun Guernica'sı hala savaş karşıtlığının simgesi konumundadır.

Bir yandan UNESCO Dünya Kültürel Mirası Listesi'nde yer alan Suriye'deki Palmira Antik Kenti IŞiD tarafından yok edilirken, diğer taraftan mülteci dramının yaşandığı bu toplumsal travma ortamında, Dünya'nın çeşitli bölgelerinde yaşayan sanatçılar yaşananlara tepkisiz kalmamışlardır Çinli politik sanatçı ve aktivist olan Ai Weiwei, İngiliz grafiti sanatçısı Banksy, Suriye'li sanatçı Tammam Azzam gibi birçok sanatçı sanatla tepki ve ifade yoluna gitmişlerdir.

\section{Savaş Olgusunun Temelleri}

Geçtiğimiz yüzyıl topyekûn bir şekilde meydana gelen etkileri ile Dünya tarihini kökten değiştiren iki Dünya savaşına şahitlik etmiştir. Aradan bir yüzyıl geçmiş olsa da savaş olgusu en ilkel zamanlarda insanlık tarihine nasıl girdiyse ya da geçtiğimiz yüzyıl da iki dünya savaşına nasıl dönüştüyse aynı mantık ile varlığını hala sürdürmektedir. İçinde bulunduğumuz modern yüzyılda ise kapitalist düzenin en popüler kavramlarından biri olan sürdürülebilirlik kavramı savaş olgusunu güncel bir şekilde insanlık hayatında her türlü vahşeti ile var olmasını desteklemektedir

Savaş tarihine kısaca bakıldığında karşılaşılan ilk örneklerde Sümerlerin yaptırdığı su kanalları yüzünden suyun akışında bulunan diğer devletlerin sudan yeteri kadar faydalanamaması görünüyor. Günümüze geldiğimiz de ise en yüzeysel hali ile kapitalist sistemin devamlılığı için gerekli hammadde kaynaklarına ulaşma ve sistemin sürekliliğini koruma güdüsü görünmektedir. Savaşlar zaman içinde farklı nedenler ile başlamış gibi görünse de temelde topluluk halinde yaşama ve bunun devamlılığını sağlamak için güç gösterilerine dayanmaktadır. Sander'e (1998:533) göre;" Binlerce yıldır olduğu gibi, bugün de insanlığın karşısındaki sorun, kimin yönetip kimin yönetileceği, kimin statükoyu koruyup kimin bozacağıdır. Kaba güç ve çıkar, uluslararası ilişkilerin hala en önemli ögesidir. Dünya olaylarının sonucunu belirleyen, çatışan çıkarlar ve sürekli değişim gösteren kuvvet düzeyleridir. Toynbee (1997:9) ise Dünya tarihinde savaşları şu şekilde yorumlar;" Başlama olasılığı, geçime göre bir varsıllık fazlalığı, özdes biçimde, en az bir düzeyde teknik ve düzenleme gerektirdiğine göre, savaş, gerçekten uygarlığın çocuğudur". Buna karşılık ABD'li antropolog Margaret Mead (1940:402-405) ise savaşın bir insanlık icadı olduğunu söylemiştir.

Savaş olgusunu temellendiren birçok araştırmacıya göre savaş bireyde yer alan saldırganlık dürtüsünün bir ürünüdür. Hatta "Sigmund Freud saldırganlığı cinsellikle birlikte insanda var olduğunu savunduğu iki temel içgüdüden biri olarak görmektedir" (Merkit,2016:137). Bir başka kuram sahibi olan Robert Andrey'in saldırganlık kavramının savaşma dürtüsüne dönüşmesi üzerine değerlendirmelerini Elitok şu şekilde aktarmaktadır;

Amerikalı antropolog Robert Ardrey, bireysel saldırganlığın grup saldırganlığı biçimine dönüşmesini açıklarken, insanların topluca avlandıkları takdirde daha başarıı olduklarını fark edip, tıpkı sürüler halinde ava çıkan hayvanlar gibi davranmaya 
alışıklarını ve ortak topraklar üzerinde is birliği yaparak bir çeşit toplumsal organizasyonun temelini attıklarını ve işlerine karışan diğer insanlarla savaşma dürtüsünü kazandıklarını öne sürmektedir(Elitok, 2011:6).

Savaş olgusu üzerine bireysel ve toplumsal temellendirmelerin hepsi davranışın ilkel bir çıkış noktası olduğunu zamanla insanlık gibi kendini geliştirdiğini ve her defasında kendine bir neden bulduğunu göstermektedir. Savaş olgusunu tetikleyen durumlardan savaşın etkilediği bireyler ve toplumlara bakıldığında ise kolektif belleğin en acı yaşanmışıkları ortaya çıkmaktadır. Ölüm, yaralanma, temel ihtiyaçlardan mahrum kalma, belirsizlik, çaresizlik ve bunların sonucunda hayatta kalma dürtüsü ile bireysel ve topluluk halinde göç savaşın en önemli sonuçlarıdır.

2011 yılında başlayan günümüzde hala devam etmekte olan Suriye İç Savaşı ise bütün dünyanın gözleri önünde yaşanan toplumsal bir felakete dönüşmüştür. Gelişen teknoloji, medya ve internet alt yapısı ile birlikte dünyanın herhangi bir noktasında meydana gelen herhangi bir olay anında haberlestirilmektedir. Görsel ve bilgiye hızlı bir şekilde ulașma imkânı savaşı ve etkilerini anlık izleme ve tepki verme imkanı sunmuştur. Savaşın başlamasından sonraki yıllar içinde sığınmacı ve mültecilik kapsamında kitlesel bir göç başlamıştır. Savaşın toplumsal etkileri ise geri döndürülemez boyutlardadır.

\section{Suriye İç Savaşı ve Toplumsal Sonuçları}

Suriye ya da tam adıyla Suriye Arap Cumhuriyeti, uzun yıllardır Beşşar Esad yönetiminde bulunan baskıcı Baas Partisi iktidarı tarafından yönetilmektedir. 2011 yılında bu baskıcı tutuma karşı muhalifler tarafından da desteklenen toplumsal olaylar meydana gelmiştir. Eylemcilerin ortak talepleri ise; issizliğin ve yolsuzluğun önlenmesi, baskıcı tutumun ortadan kaldırılıp özgürlüklerin artırılması şeklinde ifade edilmiştir. Barışçıl eylemler şeklinde başlayan protestolar Esad yönetimi tarafından ateş emri verilmesiyle ülke geneline yayılan bir iç savaşa dönüşmüştür.

Zamanla ülke içinden ve dışından çeşitli radikal terör örgütlerin bir araya gelmesiyle savaşın seyri ve şiddeti de artmıştır. Kalyvas'a göre; "iç savaşın en temel özelliklerinden biri savaşa dâhil olan grup veya kitlelerin bölgesel özerklik iddialarıdır. Bunun yanında, savaşa dâhil olan gruplar koalisyon oluşturabilir ya da birbirlerinden bağımsız hareket edebilir, uluslararası düzeyde tanınabilir ya da izole edilebilir" (Kalyvas, 2006:18). Kalyvas'ın bahsettiği gibi çeşitli amaçlar doğrultusunda Suriye'nin farklı bölgelerinde eli silahlı grupların hem kendi aralarında hem de mevcut Suriye hükümeti ile çatışmalar meydana gelmiştir. Bu eli silahlı gruplardan en dikkat çeken ise IŞiD terör örgütü olmuştur. Özellikle Suriye içerisinde ki sivil halka yönelik ve sınır komşusu Türkiye başta olmak üzere çeşitli ülkelerde kanlı eylemler düzenlemişlerdir.

Suriye İç Savaşı etkileri ile İkinci Dünya Savaşı sonrasında yaşanan en büyük insanlık dramını da beraberinde getirmiştir. Özellikle IŞiD terör örgütü olmak üzere, Suriye mevcut hükümeti ve çeşitli ayrılıkçı grupların saldırıları karşısında en büyük zararı sivil halk görmüştür. Artan sivil can kayıplarının yanında ekonomik, sosyal, kültürel anlamda da toplumsal bir çöküş yaşanmıştır. En temel hayatta kalma güdüsü ile milyonlarca insan sığınmacı ve mülteci olarak başka ülkelere göç etmek durumunda kalmıştır.

Barışçıl protestolar ile başlayan sonunda bir iç savaşa dönüşen bu sürece politik, ekonomik, sosyolojik, kültürel ve en önemlisi insanı açıdan birçok yaklaşımlar geliştirilmiš. Kayıpları ve travmalarıyla birlikte analizler yapılmıs ve yapılmaya devam edilmektedir. Bu makalenin devamında buraya kadar kısaca anlatılan durumla ilgili kültürel ve özellikle sanatsal yaklaşımlara değinilecektir. Sanatın tasvir etme gücüyle Suriye İç Savaşı'nı ve toplumsal etkilerini nasıl gördüğü üzerine durulacaktır.

\section{Sanatsal Yaklaşımlar Bağlamında Savaş Olgusuna Bakış ve Suriye İç Savaşı}

Toplum merkezli sanatsal yaklaşıma göre sanat toplumdan bağımsız değildir. Sanatçı toplumun bir parçasıdır, içinden çıktığı ya da beraber yaşadığı diğer Dünya milletlerinin acılarına tepkisiz kalmaz yani sanat yansıtmacıdır. Tarihsel süreçte bu bağlamda sanatın gözünden savaşa çeşitli yaklaşımlar geliştirilmiştir. Bazen savaş sadece bir tema olarak görülmüştür.

Paolo Uccello'nun "San Romano Savaşı (1432)" adlı eserinden günümüze değin birçok sanatçı, savaş temasını resimlerinde kullanmıștır. Ancak burada önemli bir noktayı belirtmekte yarar var; sanatlarında savaşı bir tema olarak algılayan, söz konusu sanatçıların yapıtlarını salt tarihsel bir olayı betimlemeleri gibi düşünülmemelidir. Bu türden bir kavrayış oldukça eksik bir düşünme yöntemini beraberinde getirmektedir; çünkü sanat, gerçekliğin kavranışı bakımından hayat karşısındakı konumunu, ancak diyalektik düşünme biçimiyle sahici bir zeminde tarif edebilir (Aslan ve Karaaslan, 2016:49)

Bazen de sanatçı sanatını, savaşın kazananı tarafından bakarak bir yüceltme ve kahramanlık destanını şeklinde yansıtmıştır. Gerçekte ölüm, kan ve yıkımdan oluşan savaş alanı ressam tarafından destansı betimleler ile tasvir edilmiştir. Örneğin "Paolo Uccello'nun "San Romano Savaşı" (1438-40) adlı eseri sanatçının kendi üslubunu ortaya koyan önemli bir yapıttır. Eser, 
1432 yılında Sienalıların bozguna uğramaları ve Floransa'nın zaferiyle sonuçlanan San Romano Savaşını resmetmektedir. Sanatçı bu eseri Medici Ailesi için yapmıştır" (Ülger, 2014: 160).

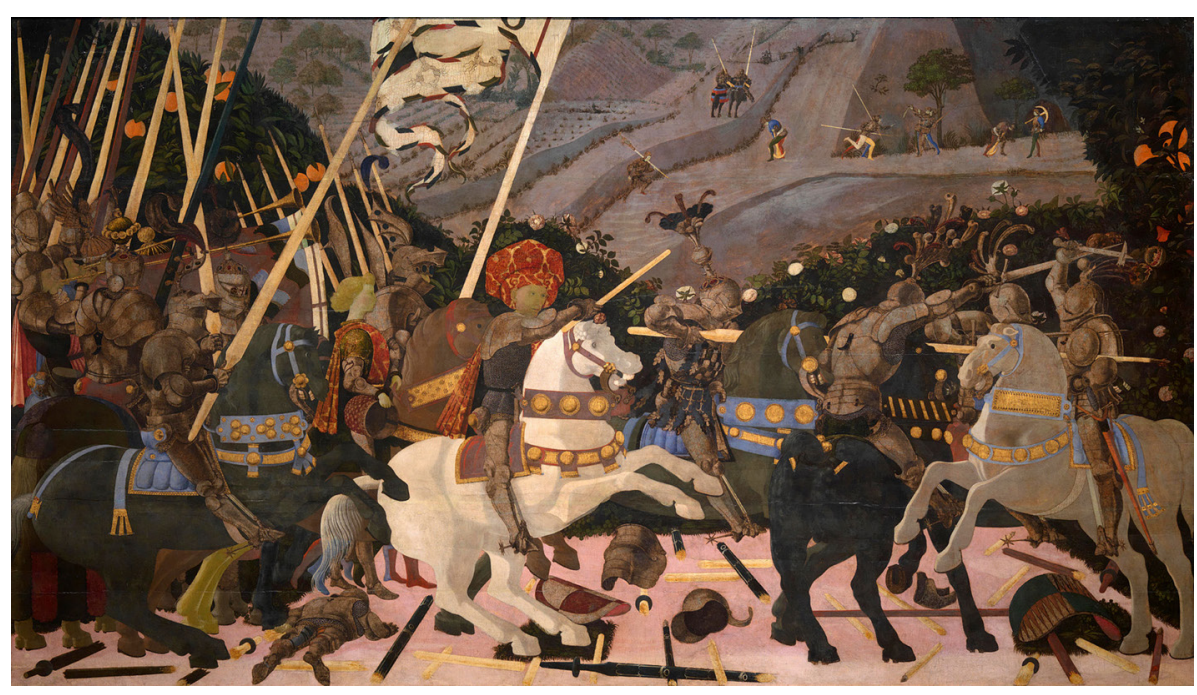

Görsel I. Paolo Uccello, San Romano Savaşı, 1438-40, Pano Üzerine Tempera, $182 \mathrm{~cm} x$ $320 \mathrm{~cm}$

Bazen de sanat bir savas ortamında propaganda aracı olarak politik üstünlük için kullanılmıştı. Özellikle Hitler Almanya'sı ve İkinci Dünya savaşı sürecinde bașta sinema olmak üzere sanatın çeșitli dallarının bir propaganda aracı olarak kullanılmıştır. Nasyonal sosyalist ideoloji temelinde kurulan Halkı Aydınlatma ve Propaganda Bakanlığı birçok fikrini sanatsal araçlar yoluyla halka benimsetmeyi başarmışı. Bunun dışında Lenin'inde sanatı bir propaganda aracı olarak kullandığı bilinmektedir. Ekim Devrimi sonrasında ortaya çıkan ic savaşlarda halkın devrim heyecanını kaybetmemesi amacıyla çeşitli sanatsal aktiviteler yapılmıştır. Resim bu sanatsal eylemlerden biri olmuştur.

Sanatçı Vladimir Aleksandroviç Serov liderleri Lenin'i genelde kendisi gibi düşünen ve bu uğurda savaşan halkla beraber betimlemiştir. Resimlerde Lenin'in görüntüsünün tasvir edilmesinden ziyade, düşüncelerinin halka geçmesi ve taraftar toplamas daha önemlidir. Ayrıca bu dönemdeki propaganda çalışmalarının amacı halka savaşın nedenlerini ve savaşın sonucunda elde edilecek faydaları bütünsel bir şekilde anlatmak ve taraf toplamaktı (Kurt, 2018: 181).

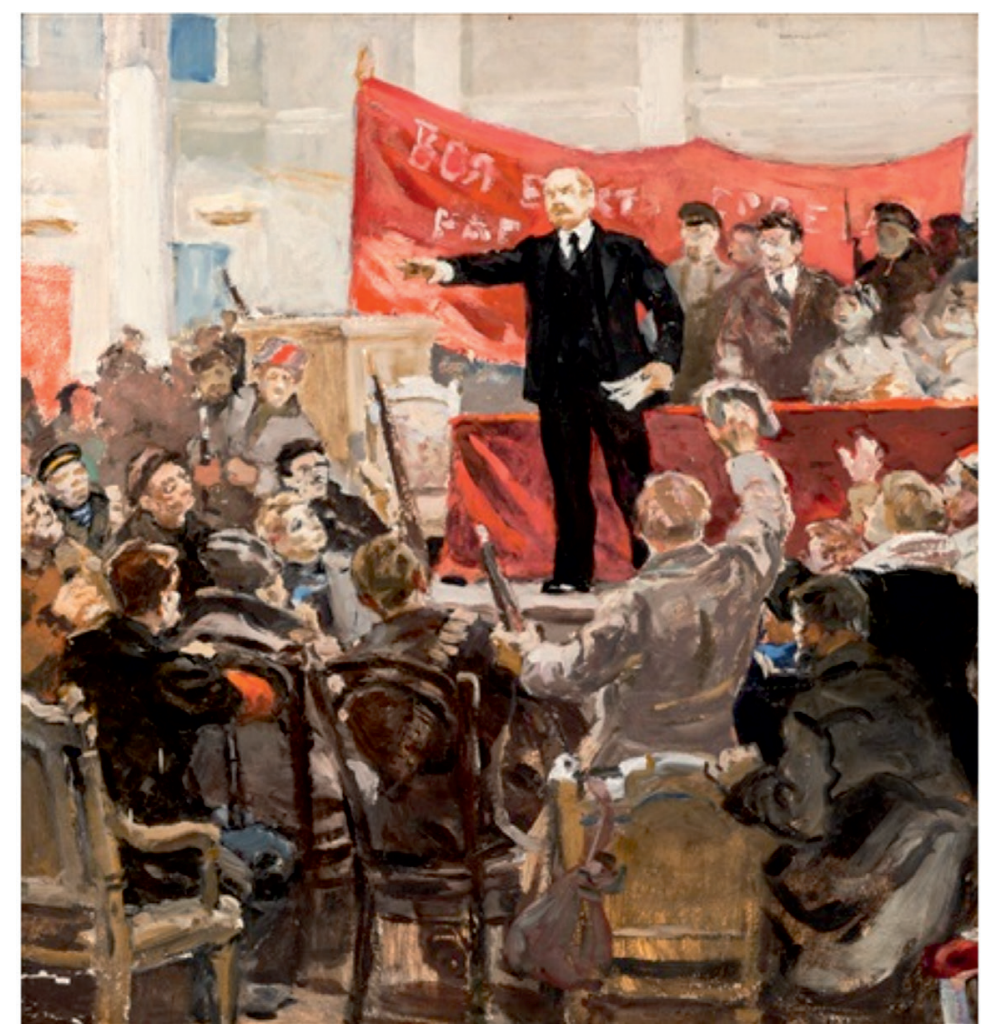

Görsel 2. Vladimir Aleksandrovich Serov, Proclamation of the Soviet Government,

Tuvale Yağıboya, $53 \times 5 \mathrm{Im}$

Çinli komutan Sun Tzu ise savaşın kendisini bir sanat olarak görmüş ve "Savaş Sanatı'nı" yazmıştır. Bazı sanatçılar ise savaşı insan tepkilerini gözleme fırsatı olarak değerlendirmişlerdir. Bir yandan inanmışık ve kahramanlık duyguları ile savaşan taraflar diğer tarafta hayatta kalmaya çalışan korkmuş insanlar topluluğu ortaya çıkmışır.

Sanat penceresinden savaşa yönelik farklı yaklaşımdan duyarlııkların en üst seviyeye çıktığı günümüz modern toplumuna gelindiğinde ise savaş, her hali ile kınanması ve elestirilmesi gereken bir olguya dönüşmektedir. Teknolojinin bu kadar geliştiği bir ortamda her türlü bilgi ve görsele anlık ulaşım imkanında, savaşa ve yaşanan insanlık dramına duyarsız kalmaksa ayrıca sorgulanması gereken bir durumdur. Burada tartışma yaratacak tek durum fazla maruz kalmanın getirdiği durumu olağanlaştırma sorunsalıdır. Örneğin; geri dönüp bakıldığında Napolyon'un askerlerinin İspanyol halkına zulmünü hatırlatan en önemli simge Goya'nın "3 Mayıs 1808" adlı ese- 
ridir veya İspanya iç Savaşı'nın simgesi Picasso'nın "Guernica" çalışmasıdır. Ya da Vietnam Savaşının simgesi olarak gösterilen Nick Ut tarafından çekilen, ABD'nin attığı bombalardan çıplak şekilde kaçan kız çocuğu fotoğrafı veya Chris Burden'in 1971 yılında yine Vietnam Savaşını protesto etmek için gerçekleştirdiği "Shoot" isimli cesur performansıdır. Burden savaşta hayatını kaybedenlerin ya da yaralanların medyada sadece birer sayı olarak yer almasına tepki çekmek için yakın mesafeden bir arkadaşının yardımı ile tüfekle kendine ates açtırmıstıı. Bu performansı neticesinde kolundan vurulmuştur. Bir savaşı bir resim, bir görsel, bir edebi eser, bir müzik veya performans sanatı ile eșleştirmek belki günümüz toplumunda pek mümkün değildir. Bunun da nedeni hayatın her alanında olduğu gibi savaş olgusunun gerçekliğine görsel anlamda fazlasıyla maruz kalınmasıdır.

Teknoloji ve maruz bırakma bir duyarsızlaştırma nedeni mi yoksa insanlığın farkındalığı için bulunmaz bir fırsat mı tartışmaları devam ederken Suriye'de savaş hala devam etmektedir. Bu tartışmalar eşliğinde Suriye iç Savaşı'nın ve akabinde gelişen mülteci sorununun simgesi haline gelen bir fotoğraf karesi hemen hemen herkesin hafızalarında derin etkiler bırakmıştır.

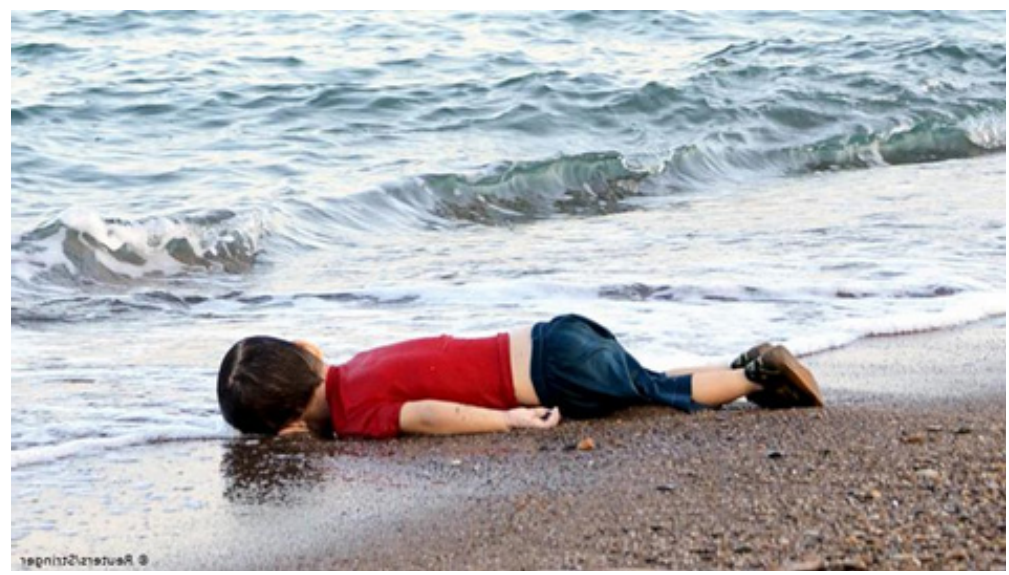

Görsel 3. Alan Kurdi, (Fotoğraf: Nilüfer Demir), 2015

Bu, Türkiye'nin Ege kıyısında yer alan Bodrum ilçesinden Yunanistan'a geçmek isterken devrilen lastik bottan sahile vuran bir trajedinin karesiydi. 2 Eylül 2015 tarihinde Doğan Haber Ajans'ından Nilüfer Demir'in objektifine yansıyan karede sahile vurmuş 3 yaşındaki bir çocuğun cansız bedeni vardı (Görsel 3). Bu Dünya genelinde toplumsal hafızada infial yaratacak bir kareydi. Nilüfer Demir bu fotoğraf için "yapabileceğim tek şey bu çığlığı duymaktı" demiştir. Evet ortada bir çığlık vardı savaş bölgesinden kaçarken yolda yok olan insanlığın çığlığıydı.

TIME dergisi bu fotoğraf karesini tüm zamanların en etkili 15 fotoğrafından biri olarak ilan etmiştir.

TIME fotoğraf editörleri Ben Goldberger, Paul Moakley ve Kira Pollack, bu fotoğraf karesi için, bazı fotoğrafların türünün ilk örnekleri olduklarından, toplumun düşünme tarzlarında yeni şekillenmeler yarattığını ifade etmişlerdir ve bu fotoğrafın, yaşanılan mülteci krizi üzerinden insanlığın dönüm noktasını temsil etmesi açısından önemli bir yere sahip olduğunu belirtmişlerdir. ${ }^{1}$

Alan Kurdi isimli 3 yaşındaki çocuğun cansız bedeni Dünya'da savaşın yok ediciliğine yönelik bir farkındalık yaratmıştı. Ancak Alan Kurdi bu şekilde ölen ne ilk ne de son kişiydi. Bu olaydan önce ve sonra göç yolundaki binlerce insan denizlerde boğularak hayatını kaybetti. Tüm bu yaşananlar birer trajedi olsa da aynı tarzda olaylara medya yoluyla fazla maruz kalmaktan dolayı bir duyarsızlaşma başlamıştır. Bu olay sanki hayatın olağan akışında olan normal bir durum gibi karşılanmaya başlanmıştır.

Alan Kurdi ve benzeri olaylardan sonra savaș olgusu, mülteci sorunu, vatansızlık kavramı, göç yollarında yaşanan trajediler, ülkelerin politikaları sanatçıların eserleriyle de evrensel bir boyut kazanmışlardır.

\section{Ai Weiwei}

Ai Weiwei' 'nin kişisel geçmişi Suriye elç Savaşı sonrası ortaya çıkan mültecilik konusuna daha fazla hassas davranmasına ve empati kurmasına sebep olmuştur. Weiwei, şair babası Ai Qing'in politik görüşlerinden dolayı Çin hükümeti tarafından işçi kampına sürgüne gönderilmesinden dolayı ailesi ile birlikte mültecilik hayatına hiçte uzak olmayan bir yaşam sürmüştür. Bu acı tecrübeden sonra da sanatçı kişiliğini insan hakları ihlali, toplumsal konular ve politik sorunlar hakkında eleştirel bakış açısı geliştirme üzerine olmuştur.

Günümüz teknoloji çağının en büyük getirilerinden biri olan bilgi ve görselin anında Dünya'nın herhangi ücra bir köșesinde aynı anda ulașması ortak tepkiyi de aynı anda getirmişstir. Bunun etkili örneklerinden biri de elbette sanat çevresinde söz konusu olmuştur. Alan Kurdi'nin cansız bedeninin kıyıya vurmuş fotoğrafı ilk vaka değildi fakat etkili bir vakaydı.

\section{I https:// 140journos.com/ adresinden 18 Ocak 202 I tarihinde alınmıştır.}

${ }^{2}$ Ai Weiwei(d. 28 Ağustos 1957), Çinli çağdaş sanatçı ve aktivist. Heykel, enstalasyon, küratörlük, fotoğraf ve film alanlarında aktif olmasının yanı sıra sosyal, siyasal ve kültürel bir eleştirmendir. https://tr.wikipedia. org/wiki/Ai_Weiwei adresinden 17 Ocak 202I tarihinde alınmıştı. 
Ortada büyük bir insanı dram söz konusuyken sanatçılarda sanatın temsil ve ifade gücünü kullanarak tepkilerini verme yöntemlerini geliştirdiler.

Ai Weiwei, Nilüfer Demir'in çektiği Alan Kurdi fotoğrafından etkilenerek 2016 yılında farkındalık yaratma amacıyla aynı kareyi canlandırmıştır. Amacı Dünya kamuoyuna bir şeylerin yanlış gittiğini, ortada bir insanlık dramının olduğunu anlatmaktı. Seçilen yöntem eleştirilebilir ki zaten oldukça eleştirilmiştir. Weiwei'nin tekrar canlandırma performansı ve bunun fotoğraflanıp Hindistan Sanat Fuarında sergilenmesiyle eleştirmenlerden, sanat severlerden ve farklı çevrelerden bunun densiz ve ucuz bir yöntem aynı zamanda düşüncesizce yapılmış bir reklam çalışması olduğu yönünde eleştiriler almıştır. Weiwei'in amacı da zaten dramatik bir durumun dramatikliğine daha fazla dikkat çekebilmeyi başarmaktır. Aslında bu bir tepkisel eylemdir, gerçekliğin bir yansıtmasıdır. Venturi'ye göre;" Gerçekte, eserde sadece eylemin yanılsaması vardır, eylemin kendisi yoktur. Gerçek eylemi yaratmayı hedefleyen sanatçılar, sanatın dışına çıkarlar çünkü sanatı gerçekliğe indirgemişlerdir" (Venturi, 2018).

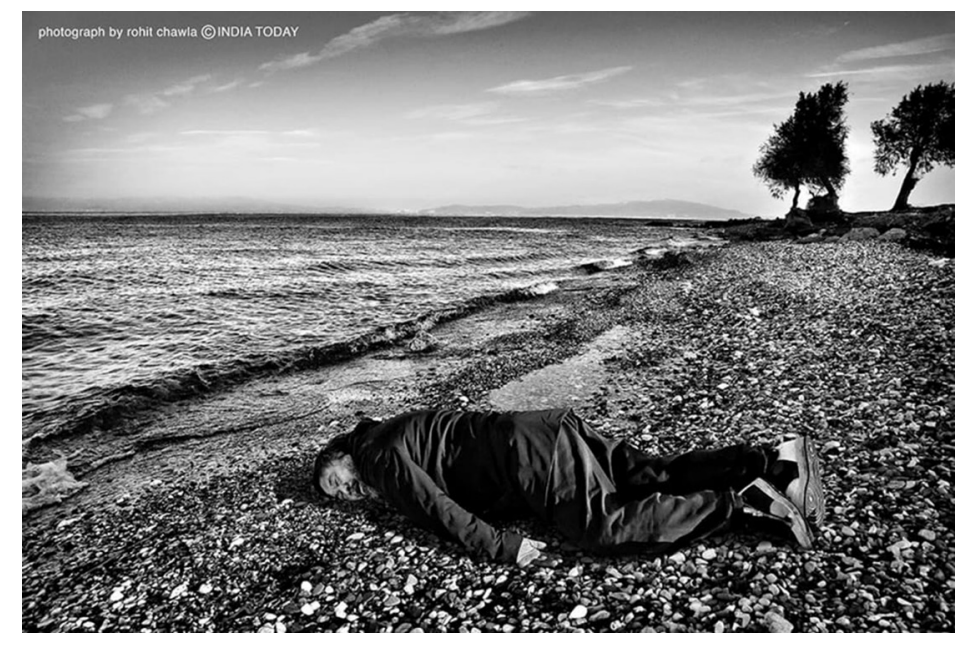

Görsel 4. Ai Weiwei, Alan Kurdi, 2016

Ai Weiwei'nin yine aynı dramatik görseli ele alarak yaptığı ikinci çalışmas ise geleneksel Çin el sanatlarından yola çıkarak yaptığı porselen üzerine yorumlamasıdır. 2017 yılında Sakıp Sabancı Müzesinde gerçekleşen "AiWeiwei Porselene Dair" isimli sergisinde de yer alan bu eser ile geleneksel bir sanat ile günümüz sorunlarını birleştirmiştir. Weiwei'nin amacı bir şekilde dikkat çekmek, kamuoyu oluşturmak ve sorunu evrensel boyutlara taşımaktır. Weiwei, politik aktivist ve sanatçı kimliğini aynı anda kullanabileceği bir üslup benimsemiştir.

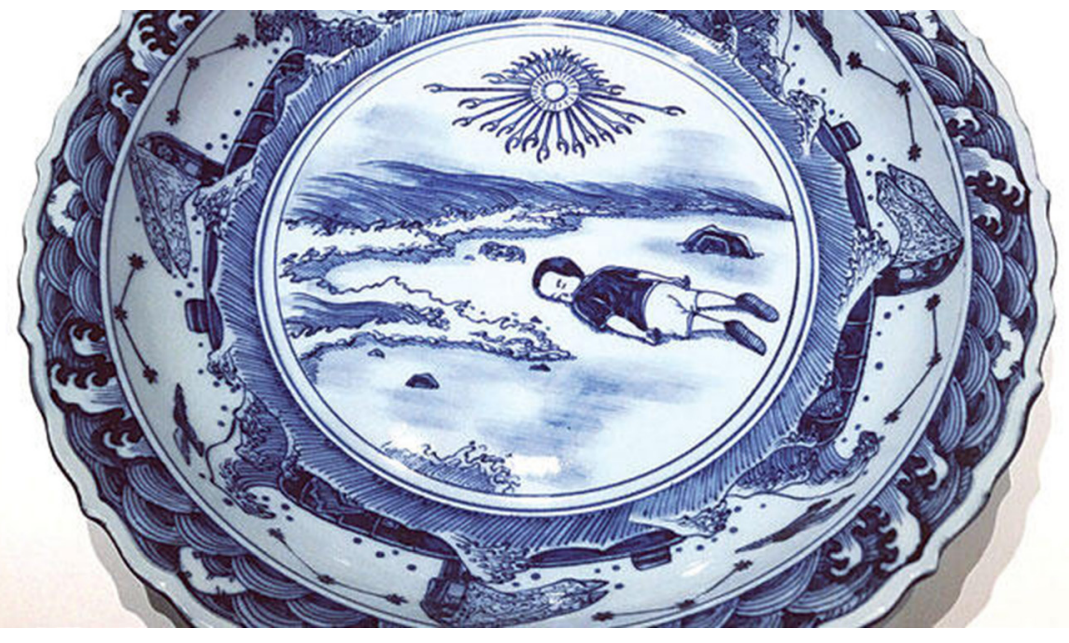

Görsel 5. Ai Weiwei, Alan Kurdi, 2016

Ai Weiwei'nin mülteci krizini ele alarak gerçekleştirdiği bir diğer çalışması ise Berlin'de gerçekleştirdiği enstalasyon projesidir. "Sanatçı bu güncel göçmen krizine dikkat çekmek için 2015'te mültecilerin bulundukları Midilli adasına stüdyo kurmuş ve bir dizi proje üretmiştir. Mültecilerden geriye kalan 14000 can yeleğini toplamış ve bunları Berlin Konzerthause (konser salonu) sütunlarını sararak bir enstalasyon oluşturmuştur" (Güzelaydın, 2016: 115).

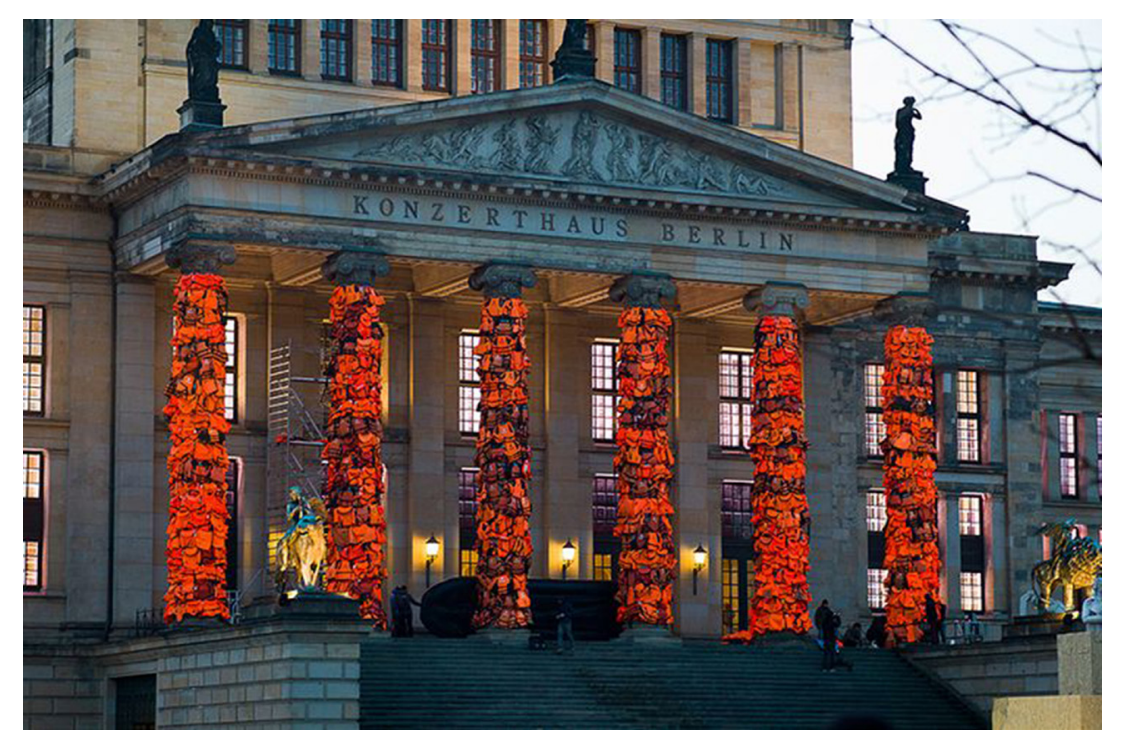

Görsel 6: Ai Weiwei, Konzerthause Binası, Berlin, 2016 
Ai Weiwei bu çalışması da diğer çalışmaları gibi dikkat çekmeye yöneliktir.

\section{Banksy}

Aslında gerçek ismi bilinmeyen "Banksy" takma adı ile uzun yıllardır kamusal alanlarda yaptığı çalışmalar ile bilinen bir sanatçıdır. Ai Weiwei gibi Banksy'de daha çok politik olaylara verdiği akılda kalıcı tepkisel çalışmalar ile bilinmektedir. Bunun yanında savaş karşıtı, çevre duyarlıığı yüksek, aşırı tüketime karşı, mülteci sorunlarıyla ilgili İngiliz gerilla sanatçısı olarak tanınmaktadır.

Banksy, aslında uzun yıllardır yaptığı çalışmalar ile bilinse de İsrail-Filistin duvarına yaptığı grafitiler ile bilinirliği daha fazla artmıştır. Savaş karşıtı tutumu ve cesaret isteyen eylemleri ile sanatçının beraber yaşadığı insanlığın sorunlarına karşı duyarsız kalamayacağını göstermiştir. Aslında Banksy sanatçı muhalif bakış açısının bir örneğidir. İsrail-Filistin arasında yıllardır sürmekte olan gerilime karşı Filistin'in sesi olmayı tercih etmiştir. Banksy, Filistin'i Dünya'nın en büyük açık hava hapishanesi olarak tanımlamıştır. Bu tanımlama hem fiziksel hem psikolojik olarak gerçek bir tanımlamadır. Filistin haritada fiziksel olarak İsrail ablukasında bir ülkedir.

Suriye İç Savaşı ve mültecilik konusu Banksy'nin duyarsız kalmadığı diğer konulardır. Mart 2014'de Suriye İç Savaşı'nın üçüncü yılında mültecilik sorununa tepki vermek için dünya çapında ikon haline dönüşen Kırmızı Balonlu Kız çalışmasını tekrar uyarlamıştır.
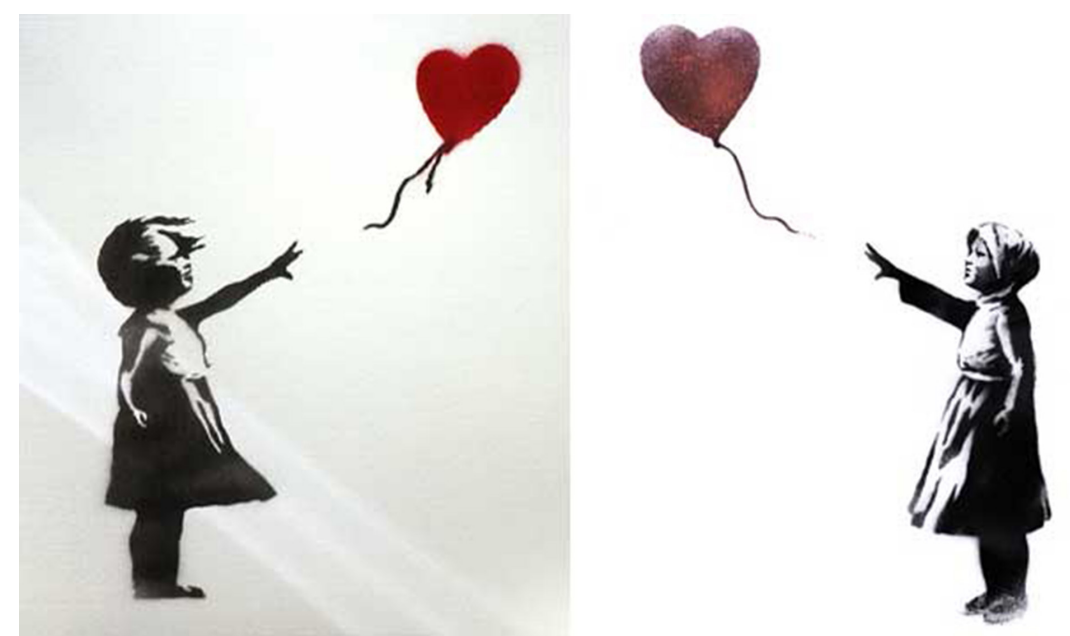

Görsel 7. Banksy, Kırmızı Balonlı Kız, 2002 ve Yeniden Uyarlanmış Versiyonu, 2014
Amacı olayın evrensel boyutlarına dikkat çekmektir. Çünkü savaş tek başına meydana geldiği ülke ya da ülkeleri ilgilendiren bir ķonu değildir yaşanan küresel bir sorundur. Suriye İç Savaşı da kelebek etkisi gibi yavaş yavaş bütün Dünya'nın sorunu haline gelmiştir. Mültecilik, Suriyeli mültecilik ve ailesini kaybetmiş çocuk mültecilik kavramları artık bütün insanlığın sorunudur. Banksy bu yeniden uyarlama çalışması ile özellikle çocuk mülteciliği üzerine durmuştur.

Banksy'nin Suriye iç Savaşı ve mültecilik üzerine birden çok çalışması mevcuttur. Bunlardan bir tanesi ise yine mültecilik üzerine dikkat çekmeye çalıştığı Fransa'da yer alan Jungle mülteci kampında yaptığı Steve Jobs çalışmasıdır. Banksy'nin Steve Jobs'u seçmesinin önemli bir anlamı vardı çünkü Jobs'da Suriyeli göçmen bir ailenin çocuğudur. Banksy bu çalışmasını mülteci karşıtığına tepki olarak yapmıştır. Zaman zaman Türkiye'de de tepkilere yol açan mültecilerin ülke kaynaklarını tükettiği, kendi vatandaşlarına yeteri kadar imkân tanınmasına engel olduğu yönündeki tezleri çürütmek istemiştir. Steve Jobs bir göçmen çocuğuydu ama Dünya'nın en zengin insanlarından biri olmayı başarıp ödediği vergiler ile yaşadığı ülkeye artı değer kazandırabilmişti.

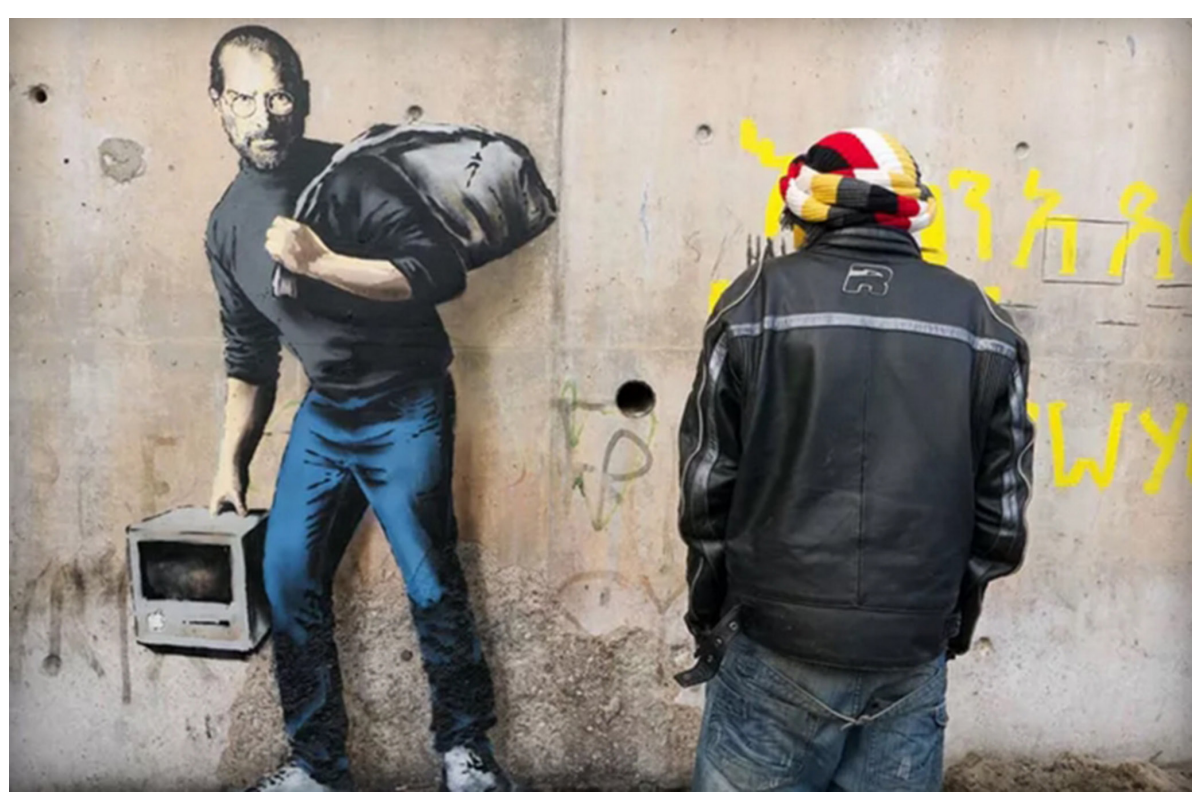

Görsel 8. Banksy, Suriyeli Bir Göçmenin Oğlu, 2015 
Banksy, aslında yaptığı çalışmaların çoğunda sade bir dil kullanmıştır amacı vermek istediği mesajı dolaysız bir şekilde vermektir. İnsanları, insanlığın ortak sorunları hakkında düşünmeye itmek, toplumsal bir kamuoyu oluşturmak ve aslında sorunların çoğunun da politik birer unsurun sonucu olduğunu vurgulamak istemiştir. Bu bağlamda Banksy'nin düşünceler sadece şablon kullanarak duvarlara yaptığı tepkisel çalışmaların ötesine geçtiği de görülmektedir. Banksy 2020 yilında Avrupa'ya deniz yolu ile ulaşmaya çalışan mültecileri kurtarmak için Fransız donanmasına ait bir botu satın almak için finansal destek sağlamışır. Feminist ve anarşist olarak tanımlanan Louise Michel'in adını taşıyan bu kurtarma botu için yaptığı desteği şimdiye kadar ki en büyük eseri olarak tanımlamıştır. Banksy kurtarma botunun üzerine "Kırmııı Balonlu Kız" çalışmasına gönderme yapan bir şablon uygulaması yapmıştır.

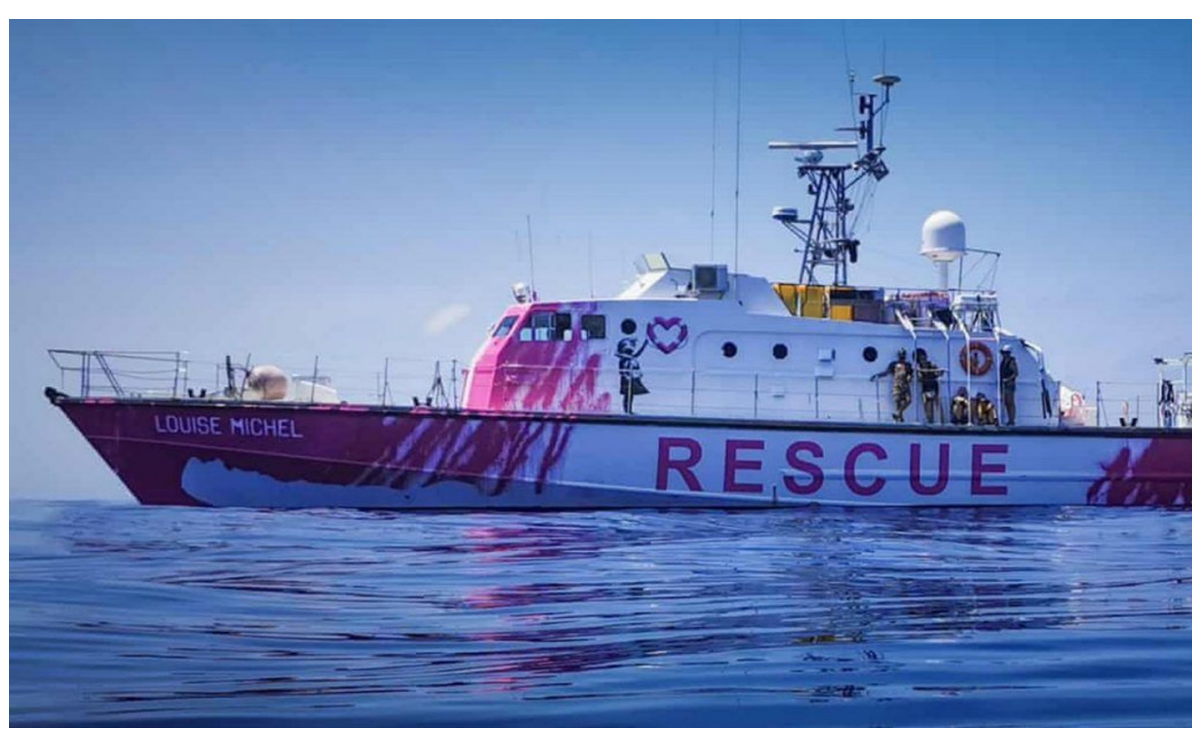

Görsel 9. Banksy, 2020

Anny Shaw'ın The Art Newspaper yayınladığı makalesindeki bilgiye göre; "Almanya'da kayıtlı ve Pia Klemp liderliğindeki Avrupa'nın dörtbiryanından bir aktivist ekibi tarafından yönetilen kurtarma botu, İspanya'nın Burriana limanından bir hafta önce hareket ettiğinden bu yana, Libya kıyılarında 150'den fazla kişiyi kurtarmışıı." (Shaw, 2020).

\section{Tammam Azzam}

Tammam Azzam ${ }^{3}$ hayatına ve çalışmalarına Suriye'de devam ederken Suriye iç Savassı'nın başlaması ile çalışmalarının içerikleri de değişmeye başlamıştır. Günlük hayatın değişen iklimine ve yaşanan toplumsal olaylara sessiz kalmamıştır. Çalışmalarında savaşın izlerini ve sanatın naifliğin birlikte görmek mümkündür. Tamman Azzam'ın tanınmasına yol açan en ünlü çalışmaları savaşın izlerini taşıyan yıkılmış binalar üzerine yaptığı dijital enstalasyon çalışmalarıydı. Harabeye dönmüş eski yaşam alanlarını ünlü tablolar ile birleştirip bir viral oluşturup dikkat çekmeyi başarmıştır.

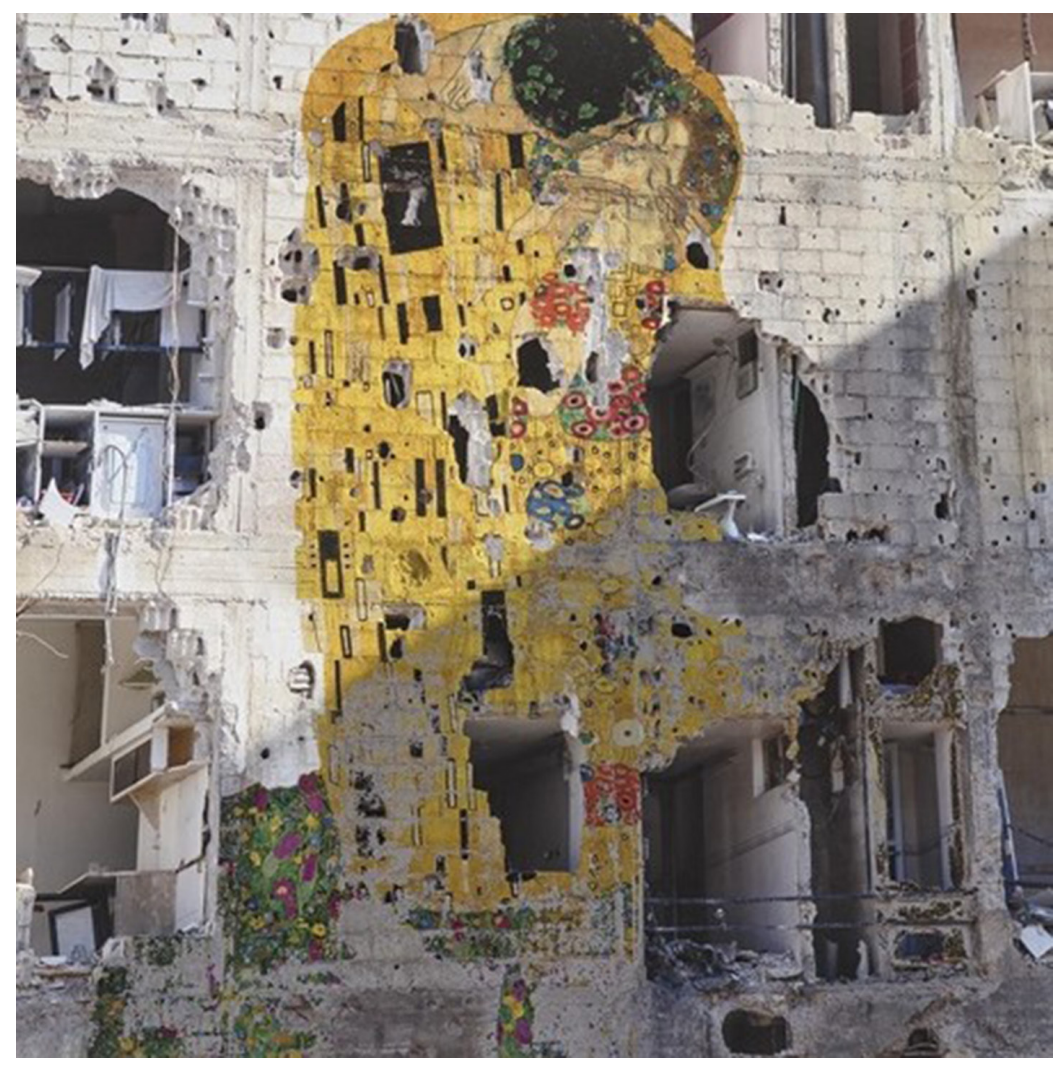

Görsel 10. Tammam Azzam, Freedom Grafitti, 2013

Tammam Azzam, 1980 Sam/Suriye doğumlu bir sanatçıdır. Daha çok grafik tasarım, illüstrasyon ve dijital sanatlarla ilgilenmekle birlikte Şam Üniversitesi Güzel Sanatlar Fakültesi'nden mezun olmuştur. Çalışmalarının birçoğunda ünlü sanatçıların klasikleşen çalışmalarını metafor olarak kullanmıştır. 
Tammam Azzam Görsel 10'da yer alan çalışması ve benzerleri için şöyle demiştir;

Biz Suriye'de komedi ve trajedinin ince çizgisini betimliyoruz. Bu durumda nasıl sanat yapılabildiğini gösteriyoruz. Umuttan, insanların savaşa karşı koymalarından, sevgiden dem vuruyoruz. Ben de GustavKlimt'in Öpücük eserini kullanarak ilgi çekmek istedim. Sanırım burada insanları sanatla ilgilenmeyi bıraktı çünkü Suriye'de yaşanan her saniye ölüm kokuyor. Ama ben bir sanatçıyım asker değilim, benim mücadele yolum budur (Seyitvan, 2017:48-49).

Azzam'ın bir diğer çalışması ise ünlü İspanyol sanatçı Goya'nın "3 Mayıs 1808" çalışmasını ile oluşturulan fotomontaj çalışmasıdır. Goya'nın savaş kurbanlarını resmettiği ölüm, acı ve direnişin simgesi olan çalışması bu tarzda yapılmış ilk ve simge çalışmalardandır.
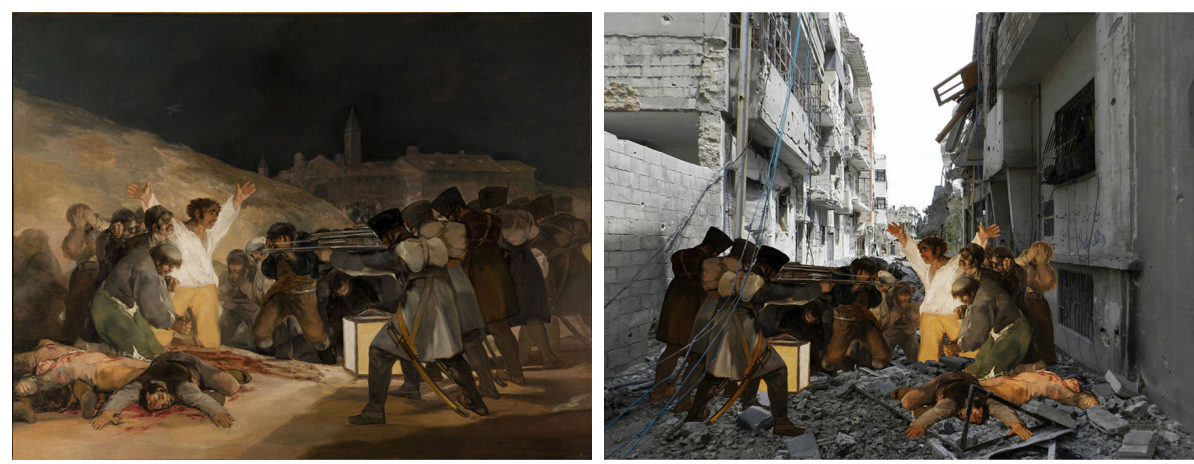

Görsel II-I2. (Solda) Francisco Goya, 3 Mayıs 1808,I8/4, (Sağda) Tammam Azzam, Goya, Fotomontaj, 2013

Goya resminde bir katliamı tasvir etmektedir. Fransız idam mangası, ìspanyol esirleri oldukça yakın bir mesafeden öldürmek üzeredir. Bazılarının öldürüldüğü görülmektedir, diğerlerinin yüzlerinde de acı ve korku vardır. Resim genel olarak karanlık bir görüntüye sahiptir fakat tam ortada bir aydınlık görülmektedir. Beyaz gömlekli kollarını yukarı kaldırmış adamın üzerine yerde duran fenerden bir ışık yansımaktadır. Kollarını yukarı kaldırmış adam ifadesi ile bir direnişi simgelemektedir. Resim başlı başına savaşın acımasız yüzüne bir göndermedir. Azzam ise bu resimden yola çıkarak harabeye dönmüş Suriye'de bir sokak görüntüsü üzerine fotomontaj yapar. Aslında vermek istediği mesaj hangi yüzyılda olursa olsun, hangi kültürde olursa olsun savaşın bıraktığı izler hem sokakta hem insanda aynıdır. Sanat ise bu ortak acıyı bazen dikkat çekmek için bazen de unutturmamak için insanlığın kolektif belleğine işlemenin en naif ve çarpıcı yoludur.

\section{Sonuç}

Geçmişe dönüp tarih sayfalarına bakıldığında insanın en ilkel davranışlarından biri olan savaşmak eyleminin günümüz modern dünyasında varlığını koruduğu görülmektedir. Amaçlar ve araçlar değişse de savaş arkasında bol miktarda acı ve ölüm bırakan etkileri ile toplumsal yapıyı değiş̧iren sonuç itibariyle pek kazananı olmayan insanlığın ortak sorunudur.

2011 yılında başlayan ve hala devam etmekte olan Suriye İç Savaşı ise etkileri ile hem Suriye halkını hem komşularını hem de Dünya'yı etkilemiştir. Suriye'de savaş devam ederken ülke vatandaşları içinse hayatta kalma savaşı başlamıştır. Bu ifade hem savaşın oluşturduğu ortamdan kaynaklı gerçek bir durumu ifade ederken hem de mültecilik için başlayan göç durumunun getirdiği bir sonuçtur. Ya kalıp ölümü beklemek ya da göç edip yolda ölmek gibi bir dilemma doğurmuştur.

Suriye İç Savaşı'na yönelik Dünya'nın birçok yerinden tepkiler gelmiştir. Savaşın kendisi kadar mültecilerin durumu da dikkat çekilmesi gereken bir başka konudur. Bu durumdan yola çıkarak birçok sanatçıda gerek tepkisel gerek dikkat çekme amaçlı çalışmalar yapmıştırlar. Sonuç olarak sanat ve sanatçı içinden çıktığı toplumların sorunlarına kayıtsız kalamamışlardır.

Bu noktada geliştirilen yaklaşım savaşı bir tema olarak kullanma ya da insan duygularını gözlemleme için bir fırsat olarak görmekten ziyade evrensel boyutta dikkat çekme üzerine olmuştur. Ai Weiwei'nin toplumsal olarak infial yaratan Alan Kurdi'nin cansız bedenin yer aldığı fotoğrafa bir tepki yöntemi olarak aynı görüntüyü canlandırması ya da bilinirliğinin temeli olan geleneksel Çin el sanatlarından olan porselene yansıtması gibi. Ai Weiwei bu yolla bir dikkat çekmeyi başarabilmiştir ama tepkiler de beraberinde gelmiştir. Yöntemi acıdan sanat devşirme şeklinde eleştiriler almıştır.

Bir diğer sanatçı Banksy ise sanatsal yaklaşımını tamamen toplumsal olaylara tepki üzerine kurmuştur. Dili çok sade yöntemi ise dikkat çekecek şekildedir. Kamusal alanları çalışma alanı olarak kullanır mesajları için dolaylı bir yol kullanmaz. İsrail'in Filistin ablukasına karşı yaptığı grafitiler ile savaş karşıtlığını göstermiştir. Suriye İç Savaşı'ndan sonra ortaya çıkan mülteci sorununu ise kendince ifade etme yöntemi bulmuştur. Toplumsal yapıyı analiz konusunda oldukça başarılı ve dikkat çekici çalışmalar ortaya çıkarmıştır.

Tammam Azzam ise savaşın toplumsal etkilerinin de Suriye İç Savaşı'nı da derinlemesine yaşamış yerel bir sanatçı olarak farklı bir ifade tarzı benimsemiştir. Bir zamanlar normal bir hayat sürdüğü içinde yaşadığı caddele- 
rin, sokakların harabeye dönmüş görüntülerinden yola çıkarak bir metafor geliştirmiştir. Savaşın tüm izlerini taşıyan bir binanın üzerine ünlü "Kiss" tablosunu yaparken belki tablonun naifliğinin binayı sarıp iyileştirmesini dilemiştir.

Teknolojinin bu kadar geliştiği, Dünya'nın global bir köy olarak adlandıııdığı, herhangi ücra bir yerde olan acının ya da mutluluğun anında herkese ulaşabildiği içinde bulunduğumuz modern toplumlarda, savaş gibi bir felakete dikkat çekmek için ekstra çaba gösterilmesi sorgulanması gereken bir durumdur. Bu kadar imkânın olmadığı toplumlarda sanatın ve sanatçıların hem zamanın analizi hem bir belge oluşturma çabası hem de dikkat çekme isteği ile yapılımış çalışmaları çok önemliydi. Birçoğu hala yaşanmış olayların sembolü, simgesi konumundadır. Peki günümüzde yapılan çalışmalar neden istenildiği kadar dikkat çekmeyi başaramıyor? Fotoğraf, video gibi materyallerin çoğalması ile herhangi bir duruma görsel olarak fazlasıyla maruz kalmamız gibi savaşın acımasızlığına da fazla maruz kalıp durumu olağanlaştırmış olabiliriz. Sanatçılar ise ister istemez savaşın ve sonuçlarının olağan bir durum olmadığını anlatmak için dikkat çekme intiyacı duymuşlardır. 


\section{Kaynakça}

Aslan, E., Karaaslan, S. (2016). "Sanatta Gerçekçilik Kavramına Savaş Olgusu Üzerinden Bakmak", İdil Dergisi, 6 (28)

Elitok, A. (20II). Savaş Fotoğraflarının Tarihsel Süreç Içinde İncelenmesi ve Zaman İçindeki Değişimi, Yüksek Lisans Tezi, Haliç Üniversitesi Sosyal Bilimler Enstitüsü, istanbul.

Güzelaydın, E. Ş. (2016). Günümüz Sanatında Yeni-Modernist Söylemler Bağlamında Dönüşen Sanatçı Tipolojisi ve Sanat Eseri,Yüksek Lisans Tezi, Dokuz Eylül Üniversites Sosyal Bilimler Enstitüsü, İzmir.

Kalyvas, S.N. (2006). Thelogic of violence in Civil War, Cambridge: Cambridge University Press, 18

Kurt, S. (2018). Birinci Dünya Savaşında Propaganda. Illetişim ve Propaganda, Eğitim Yayınevi, 159-196

Margaret, M. (1940). "War is Only an Invention, not a Biological Necessity”, Asia, 40(8), 402- 405

Merkit, N. (20I6). "Sigmund Freud'da Uygarlığın Temel Dinamikleri ve Birey Üzerindeki Etkisi”, Felsefe ve Sosyal Bilimler Dergisi, I37

Sander, O. (1998). Siyasi Tarih, Illk Çağlardan 1918'e, Ankara: İmge Kitabevi, 533

Seyitvan, B. (20I7). Çağdaş Sanat Bağlamında Göç ve Mültecilik, Yüksek Lisans Tezi Mardin Artuklu Üniversitesi Sosyal Bilimler Enstitüsü , Mardin.

Toynbee, A. (1997). Savaş ve Uygarık, (Çev. Mehmet Dündar), Ankara: Ürün Yayınları.

Ülger, K. (20I4). “Paolo Uccello'nun San Romano Savaşı Adlı Eserinin Resim Sanatına Etkileri”, I. Uluslararası Güzel Sanatlar Bilimsel Araştırma Günleri Kongre Kitabı, Cumhuriyet Üniversitesi Yayınları, Sivas.

Venturi, L. (20I8). Resme Nasıl Bakılır? Giotto'dan Chagall'a Resim ve Ressamlar (Çev. Esra Esmert) İstanbul: Hayalperest Yayınevi.

\section{Internet Kaynakları}

İnternet: "TIME: "Alan Kurdi Fotoğrafı Tüm Zamanların En Etkili I 5 Fotoğrafı Arasında". (2I Kasım 20।6), Web:

https:// I40journos.com/time-alan-kurdi-foto\%C4\%9Fraf\%C4\%BI-t\%C3\%BCmzamanlar\%C4\%B I n-en-etkili-I 5-foto\%C4\%9Fraf\%C4\%B I-aras\%C4\%B Inda-

62e443f6। Oed adresinden I8 Ocak 202I tarihinde alınmıștır.
Internet : Ai Weiwei. Web: https://tr.wikipedia.org/wiki/Ai Weiwei adresinden 17 Ocak 202 I tarihinde alınmıştır.

Internet: Shaw, A. (2020). Banksy's activism is his greatest work. Web: https://www. theartnewspaper.com/2020/09/03/banksys-activism-is-his-greatest-work adresinden 8 Aralık 202I'de alınmıştır.

\section{Görsel Kaynakları}

Görsel I. https://tr.wikipedia.org/wiki/San_Romano_Muharebesi_(Uccello) (Erişim Tarihi: 09.12.2021)

Görsel 2. http://www.artnet.com/artists/vladimir-aleksandrovich-serov/ proclamation-of-the-soviet-government-QYyNIYODyTT_PROerve-Rw2 (Erişim Tarihi:08.12.2021)

Görsel 3. https://www.dw.com/tr/alan-bebe\%C4\%9Fi-unutma/a-45409969 (Erişim Tarihi: (8.01.2021)

Görsel 4. https://edition.cnn.com/style/article/ai-weiwei-alan-kurdi-syria/index.html (Erişim Tarihi:|8.0I.202I)

Görsel 5. https://www.hurriyet.com.tr/kitap-sanat/ai-weiwei-bogazda-40575975

(Erişim Tarihi: 18.01.2021)

Görsel 6. http://www.sanatatak.com/view/ai-weiweiden-yeni-can-yelegienstalasyonu (Erişim Tarihi:07.12.202I)

Görsel 7. http://www.milliyetsanat.com/haberler/plastik-sanatlar/banksy-den-suriyesavasinin-3-yilina-resim/37I7 (Erişim Tarihi: I8.01.202I)

Görsel 8. https://www.webtekno.com/internet/banksy-den-suriyeli-gocmenincocugu-adli-mukemmel-calisma-h I 3068.html (Erişim Tarihi: 19.01.202I)

Görsel 9. https://www.theartnewspaper.com/2020/09/03/banksys-activism -is-his-greatest-work (Erişim Tarihi: 08.12.2021) 
Görsel 10. http://www.artnet.com/artists/tammam-azzam/freedom-graffitisXBA54kxy72aWFKyBNassw2 (Erişim Tarihi: 19.01.2021)

Görsel I I. https://tr.wikipedia.org/wiki/3_May\%C4\%B Is_I808 (Erişim Tarihi: 20.01.2021)

Görsel I2. https://www.tammamazzam.com/tammam-azzam-syrian-museum-20 I3

(Erişim Tarihi: 20.01.202I) 